\title{
THE POPULARITY FAERLINA US - WORLD OF WARCRAFT CLASSIC SERVER: A GAME STUDY USING QUALITATIVE RESEARCH METHOD ON THE WORLD OF WARCRAFT CLASSIC GAME SERVER
}

\author{
Deddy Stevano H. Tobing \\ Jurusan Desain Grafis, Politeknik Negeri Media Kreatif \\ Korespondensi: Jalan Srengseng Sawah, Jagakarsa, Jakarta Selatan \\ Surel: deddy.tobing@polimedia.ac.id
}

\section{INFO ARTIKEL}

Sejarah Artikel:

Diterima: 19/11/19

Direvisi: 06/01/20

Dipublikasikan: 31/01/20

e-ISSN: 2721-0995

Kata Kunci:

MMORPG

WoW Classic

Twitch.tv

Game Server

Faerlina US

Keywords:

MMORPG

WoW Classic

Twitch.tv

Game Server

Faerlina US

\begin{abstract}
ABSTRAK
Popularitas Faerlina US - World of Warcraft Classic Server: Kajian Game Menggunakan Metode Penelitian Kualitatif terhadap Server Game World of Warcraft Classic. Penelitian ini membahas mengenai popularitas dari Faerlina US yaitu salah satu server game dari game World of Warcraft Classic (WoW Classic), sebuah game bergenre MMORPG (Massively Multiplayer Online Role Playing Game) yang merupakan salah satu versi game World of Warcraft yang di release pada 26 Agustus 2019. Penelitian ini menggunakan beberapa metode penelitian kualitatif yaitu observasi partisipatif, wawancara mendalam, dan kajian penelitian-penelitian terdahulu. Hasil penelitian ini menunjukkan bahwa popularitas Faerlina US cenderung di dorong oleh popularitas para twitch.tv streamer yang bermain di server tersebut. Penelitian ini juga menunjukkan bahwa Faerlina juga menjadi populer karena menarik untuk menjadi tempat melakukan kegiatan ekonomi seperti berjualan virtual items dan melakukan transaksi gold - virtual currency menjadi real money.
\end{abstract}

\section{ABSTRACT}

The Popularity of Faerlina US - World of Warcraft Classic Server: Game Study Using Qualitative Research Methods on the World of Warcraft Classic Game Server. This research discusses the popularity of Faerlina US which is one of the game server of the game World of Warcraft Classic (WoW Classic), a MMORPG (Massively Multiplayer Online Role Playing Game) game version which is one of the World of Warcraft game version released on 26 August 2019. This study uses several qualitative research methods, namely participatory observation, in-depth interviews, and studies of previous studies. The results of this study indicate that the popularity of Faerlina US tends to be driven by the popularity of twitch.tv streamers who play on these servers. This research also shows that Faerlina has also become popular because it is interesting to be a place to conduct economic activities such as selling virtual items and conducting gold-virtual currency transactions into real money. 


\section{INTRODUCTION}

The popularity of Faerlina US as a high populated server from the game World of Warcraft Classic is quite a phenomenon. Even though there are so many servers that are available to login but many players still want to play the game in Faerlina US. The popularity of Faerlina US is not just popularize by the players and its communities but also from the game itself.

The game "World of Warcraft Classic" is the remake of the game World of Warcraft or many times referred as World of Warcraft Vanilla which was published by Blizzard Entertainment on 23th November 2004. Since the first game of World of warcraft Vanilla on 2004 until now in 2019 Blizzard Entertainment has successfully published 8 expansion to the game World of Warcraft. Their other notable successful game titles as well are Diablo, Warcraft, and Starcraft. The Game World of Warcraft Classic replicates the game experience as authentic as can be to the version of World of Warcraft that was released in 2004. Besides World of Warcraft Clasic the expanded version of World of Warcraft Vanilla are available for players to play with monthly abo up to $15 \$ /$ month.

Table 1. Tittles of World Warcraft game expansions from Blizzard Entertainment since 2004 until 2019

\begin{tabular}{|c|c|c|}
\hline Number & $\begin{array}{c}\text { Dates of Release in North } \\
\text { America Regions }\end{array}$ & Tittle and its Expansions \\
\hline 1. & 23th November 2004 & World of Warcraft \\
\hline 2. & $16^{\text {th }}$ January 2007 & $\begin{array}{c}\text { World of Warcraft: The } \\
\text { Burning Crusade }\end{array}$ \\
\hline 3. & $13^{\text {th }}$ November 2008 & $\begin{array}{c}\text { World of Warcraft: The Wrath } \\
\text { of Lich King }\end{array}$ \\
\hline 4. & $7^{\text {th }}$ December 2010 & World of Warcraft: Cataclysm \\
\hline 5. & $15^{\text {th }}$ September 2012 & $\begin{array}{c}\text { World of Warcraft: Mists of } \\
\text { Pandaria }\end{array}$ \\
\hline 6. & $13^{\text {th }}$ November 2014 & $\begin{array}{c}\text { World of Warcraft: Warlords } \\
\text { of Draenor }\end{array}$ \\
\hline 7. & 19th July 2016 & World of Warcraft: Legion \\
\hline 8. & $5^{\text {th } \text { April 2018 }}$ & $\begin{array}{c}\text { World of Warcraft: Battle for } \\
\text { Azeroth }\end{array}$ \\
\hline 9. & $\begin{array}{c}\text { Upcoming Expansion with } \\
\text { release planned in 2020 }\end{array}$ & $\begin{array}{c}\text { World of Warcraft: } \\
\text { Shadowland }\end{array}$ \\
\hline
\end{tabular}

Faerlina US is one of the many servers that available to play for a player with active account in United States Server shows many problems because its popularity. World of Warcraft as a game with the genre Massively Multiplayer Online Role Playing Game - 
MMORPG may create many problems for game servers because the high amount load of players that play together in a single server in the same time. This research is conducted to find out why so many players play in Faerlina US while there are many servers available. Hopefully this research will help to other scholars who want to conduct research about games popularity.

\section{LITERATURE REVIEW}

\section{Popularity}

According to Cambridge dictionary popularity means the fact that something or someone is liked, enjoyed, or supported by many people. In the online etymology dictionary the word popular defined as a word that comes from the French word populaire and latin word popularis which mean accepted by the people, suited to ordinary people, well like and admired by people. Storey. (2014). P.5 said that the term popular can suggest four different meanings which are well liked by many people; inferior kinds of work; work deliberately setting out to win favour with the people; and culture actually made by the people for themselves. Storey emphasize that the mix of term popular with culture can be meant that popular culture is a residual product of high culture.

\section{Popular Game}

Asa Berger. (2002). P.7 mentioned that a popular game is made with consideration of the nature its audiences, in particular their ages and their common interests. Muriel \& Crawford, (2018). see that games, players and its culture can not be generalised into single culture because many popular video games played differently therefore, they give different experiences to players. For example, the game World of Warcraft is played differently to the game Candy Crush Saga.

\section{Massively Multiplayer Online Role Playing Game - MMORPG}

Allan (2010) describes MMORPG as game that shows the capability to develop unique language features and jargon, and also own social conventions and etiquettes, economic models, shared community values, which distinct from those of in real life. MMORPG actually creates the virtual world in a game with its fantasy aspects. Eventhough the virtual world through the technology boundaries seem so limited but it created a quite convincing immersive experience for players.

\section{Popularity of World of Warcraft - WoW}

World of Warcraft by itself is already a famous MMORPG game worldwide. There are plenty researcher conducting research about this game. Nardi (2010) wrote a book about his experience as a night elf priest in World of Warcraft. Corneliusen \& Rettberg (2008) describe digital culture, play and identity with relation of WoW. Ducheneaut, Xiong, Zhang, Yee, \& Nickell (2006) conducted research about the social dynamics in guilds inside the WoW. Billieux, Van der Linden, Achab, Khazaal, Paraskevopoulos, Zullino,\& Thorens (2013) investigated motivation to play WoW and the in game actions. 


\section{METHOD}

This research is conducted with triangulation methods which consist of participant observation, literature review and descriptive statistic analysis. Therefore, this research can create a convincing scientific result that can lead to further discussion. Wendy (2004) mentioned that in social science triangulation is a form of mixing of data or methods so through different findings create more clear views upon the topic. Triangulation often help to validate the claims in qualitative research.

Carvalho \& White (1997) mention reason researcher taking triangulation which are: the information from different methods add value to each other; or through triangulation one information can refute or conform the other information; or one information can give a new views about the topic.

\section{Participant Observation}

Barbara (2005) said that through participation observation allows researcher find rich detailed description of behaviors, intentions, situations, and events which accommodated by gaining entry into the community, participating different events and conducting formal interviews or informal conversations.

\section{Descriptive Data Analysis}

In analysing descriptive statistics researcher describes the basic features of the data that gather from credible sources through collecting usable data. Those data provide simple summaries about the sample players in Game server Faerlina US of World of Warcraft Classic. Those collected information will be describe in simple graphics analysis such as pie chart or graph chart.

\section{RESULTS AND DISCUSSION}

Researcher conduct this research as active player in Faerlina US Server for about 1,5 months from mid September 2019 to early November 2019. Researcher plays online in Faerlina US joining the faction Alliance to get close and deep information about Faerlina US. There are several findings that researcher gathered:

1. Faerlina US is so popular that cause over population in that server. This impacts on the gaming experience for players. There are negative aspects and positive aspects:

Some negative aspects are Faerlina US tend to be full; hence players might experience queue time up to 1 or 2 hours before playing. Players might also experience delay or lagging while playing. Some positive aspects are creating raid group or dungeon group will be easier than other server that might underpopulated; the economic activity in Faerlina US is activer than under populated server.

2. The Join of many streamers in the server create its own community insider the server. Faerlina US is often described as the Streamers Server because there are many notable players in Faerlina US that also a professional Internet Streamers. Those streamers's followers tend also to follow the streamer into Faerlina US. Some respected streamers 
even has own guild that can accommodate hundreds of game characters.

3. Faerlina US also attracts players with economic motives. World of Warcraft is famous for its shadow economic activity. Many players play in the server and trying collecting virtual gold that they want to exchange with real currency money through bank transfer. For example 10 Gold in World of Warcraft is similar to 1 USD in Faerlina Us.

4. Fans of streamers tend to play in Faerlina US. Many players actually want to join the guilds of many streamers such as Olympus, Crusade, Sovereign, Bajheraa's Army, Hoagie Haven Heroes, and Power. Olympus has even many copy guilds such as Olympus II, Olympus III, Olmpus IV and so on until Olympus XII and there is also Olympus Strike Force.

5. There is also increase popularity of stream sniping which is an act of ganking streamers while they are online on twitch.tv. Its created attention to many players because it shows how famous player being ganked.

6. Many players that also streamers play WoW Classic live with Twitch as their channels. Many viewers can also interact live with Twitch chat. This create also the popularity of stream sniping because many other players want to get popularity by the views on Twitch.

Table 2. Popularity of notable players in Faerlina US based on video channels data + twitters followers (9 November 2019)

\begin{tabular}{crrrr}
\hline Name & \multicolumn{1}{c}{$\begin{array}{c}\text { Twitch } \\
\text { followers }\end{array}$} & \multicolumn{1}{c}{$\begin{array}{c}\text { Youtube } \\
\text { subscribers }\end{array}$} & \multicolumn{1}{l}{$\begin{array}{l}\text { Youtube } \\
\text { views }\end{array}$} & \multicolumn{1}{c}{$\begin{array}{c}\text { Twitter } \\
\text { followers }\end{array}$} \\
\hline Payo & 109.558 & 24.500 & 3.764 .122 & 5.950 \\
\hline Staysafe & 118.413 & 29.700 & 2.881 .554 & 13.800 \\
\hline Jokerd & 149.972 & 4.110 & 259.886 & 5.500 \\
\hline Ziqo & 182.175 & 27.500 & 3.150 .035 & 20.300 \\
\hline Venruki & 267.572 & 56.700 & 11.651 .957 & 48.100 \\
\hline Esfand & 340.527 & 51.300 & 5.263 .723 & 53.300 \\
\hline Cdewx & 358.604 & 68.100 & 14.835 .173 & 64.300 \\
\hline Bajheera & 434.344 & 404.000 & 140.569 .893 & 97.900 \\
\hline Swifty & 586.534 & 711.000 & 206.966 .702 & 121.000 \\
\hline Asmondgold & 1.262 .645 & 325.000 & 76.307 .223 & 196.000 \\
\hline Sodapoppin & 2.628 .159 & 1.005 .000 & 365.621 .046 & 478.000 \\
\hline Total number & $\mathbf{6 . 4 3 8 . 5 0 3}$ & $\mathbf{2 . 7 0 6 . 9 1 0}$ & $\mathbf{8 3 1 . 2 7 1 . 3 1 4}$ & $\mathbf{1 . 1 0 4 . 1 5 0}$ \\
\hline Average & $\mathbf{5 8 5 . 3 1 8}$ & $\mathbf{2 4 6 . 0 8 3}$ & $\mathbf{7 5 . 5 7 0 . 1 1 9}$ & $\mathbf{1 0 0 . 3 7 7}$ \\
\hline Maximum & $\mathbf{2 . 6 2 8 . 1 5 9}$ & $\mathbf{1 . 0 0 5 . 0 0 0}$ & $\mathbf{3 6 5 . 6 2 1 . 0 4 6}$ & $\mathbf{4 7 8 . 0 0 0}$ \\
\hline Minimum & $\mathbf{1 0 9 . 5 5 8}$ & $\mathbf{4 . 1 1 0}$ & $\mathbf{2 5 9 . 8 8 6}$ & $\mathbf{5 . 5 0 0}$ \\
\hline Median & $\mathbf{3 4 0 . 5 2 7}$ & $\mathbf{5 6 . 7 0 0}$ & $\mathbf{1 1 . 6 5 1 . 9 5 7}$ & $\mathbf{5 3 . 3 0 0}$ \\
\hline & & & &
\end{tabular}

Through the gathered data it is clear to see that many notable players in Faerlina US has many followers in different channels such as Yotube, Twitch and Twitter. In social media such as Instagram and Facebook they tend not to be active or at least saw it as not 
important channels to contact with their viewers.

They tend also to have more followers in twitch rather than in youtube but there are slightly different results by 2 players (Swifty and Bajheera). They have more subscribers in youtube rather than in twitch. It seems that most of the streamers that play in Faerlina US see twitch as their main channel to connect with their viewer. Beside Twitch Youtube is seen also as main channel for the streamers to get connected with their viewers. It can be seen through the numbers of youtube views that reach 830 million views worldwide with mainly content of WoW Classic

Specifically from the Twich data, it can be seen that the popularity of the streamers in Faerlina US varies so much that 8 from 11 of the streamers have followers in Twitch below the average of 585.318 while only 3 players have followers in Twitch above the average from the table. Sodapoppin has the highest followers in Twitch with 2.6 million viewers while Payo has most least viewers with 109.558 .

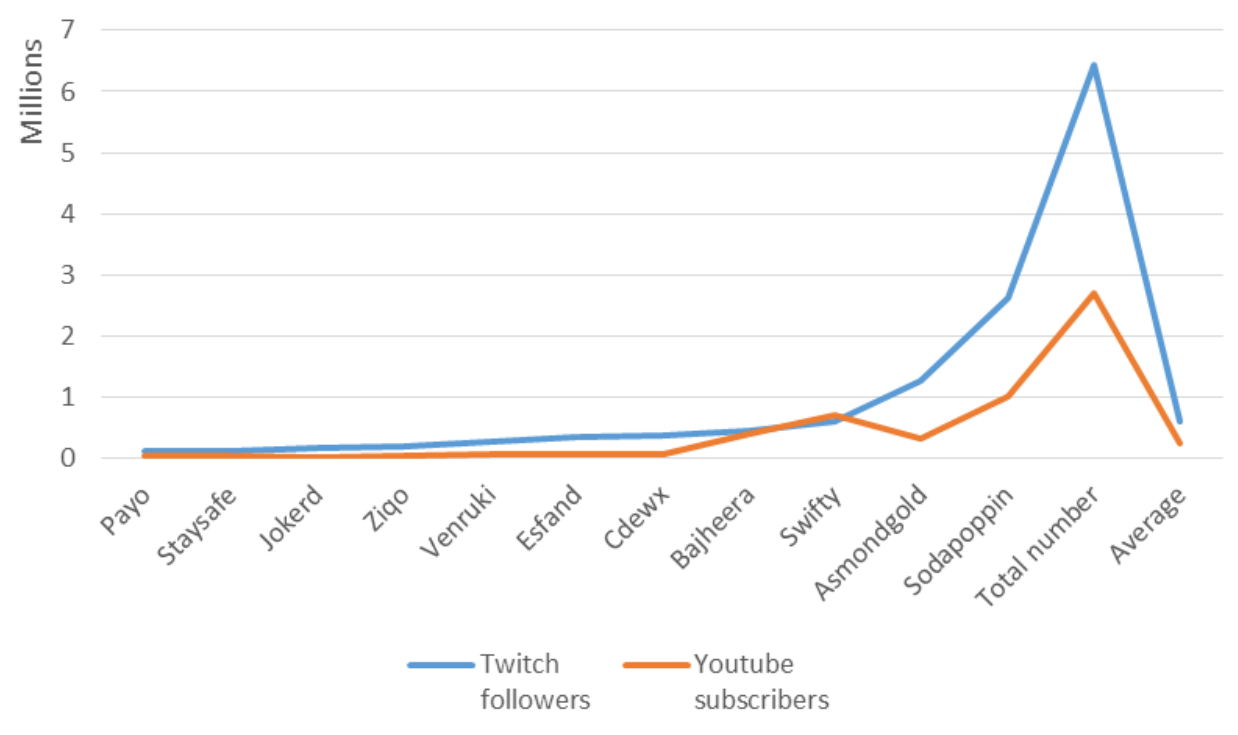

Figure 1. Comparison between Twitch followers and Youtube subscribers by the streamers in Faerlina US

Through informal interviews and chat observation it is clearly that in Faerlina US different context are being talked. Many players communicate each others through chat channels such as trade channel for more open chat, or in closed chat such as party chat, guild chat, or personal chat the so-called whisper chat. Notable themes for chats:

In game content such as trade activity for offering services or goods, or searching for members to play specific content such as dungeon or raid. Other possibly in game content is guild promotion.

Current politic themes. In trade channel or general channel there are sometimes politic themes such as discussion about president trump or hongkong current situation. 
Streamers themes. Themes about asmondgold, his Olympus guild, and other Olympus versions are also popular themes in general or trade chat. The current situation about the Olympus guild also a themes that sometimes occurred in trade chat or general chat.

Some players say that the reason they play in Faerlina US is merely because it is merely more interesting to play in full populated servers rather eventhough they admitted that they are quite familiar with the streamers through twitch.

There are also motives to create economic opportunity in Faerlina US. Some players's main intention are to farm virtual gold and searching for customers that possibly buy their gold with real currency. The current exchange rate is 1 USD for 10 Gold.

Table 3. The numbers of streamers in each faction.

\begin{tabular}{|c|c|c|c|c|c|c|}
\hline Name & Fraction & Classes & Races & Sex & $\begin{array}{l}\text { Twitch } \\
\text { followers } \\
\text { (Alliance } \\
\text { or Horde }\end{array}$ & $\begin{array}{c}\text { Youtube } \\
\text { subscribers } \\
\text { (Alliance or } \\
\text { Horde) }\end{array}$ \\
\hline Asmondgold & Alliance & Warrior & Human & Male & \multirow[b]{6}{*}{2.892 .435} & \multirow[b]{6}{*}{1.525 .110} \\
\hline Bajheera & Alliance & Warrior & Human & Male & & \\
\hline Esfand & Alliance & Palladin & Human & Male & & \\
\hline Jokerd & Alliance & Mage & Gnome & Male & & \\
\hline Staysafe & Alliance & Warlock & Gnome & Male & & \\
\hline Swifty & Alliance & Warrior & Human & MAle & & \\
\hline Cdewx & Horde & Shaman & Orc & Male & \multirow[b]{5}{*}{3.546 .068} & \multirow[b]{5}{*}{1.181 .800} \\
\hline Payo & Horde & Rogue & Undead & Male & & \\
\hline Sodapoppin & Horde & Druid & Tauren & Male & & \\
\hline Venruki & Horde & Mage & Undead & Male & & \\
\hline Ziqo & Horde & Mage & Undead & Male & & \\
\hline
\end{tabular}

Suprisingly the popularity of the streamers does not make the servers population unbalanced. The numbers of the streamers in Alliance are 6 players and in Horde 5 players with the most streamers followers in Alliance and youtube subscribers on Horde. Alliance factions are dominated with 3 warriors, 1 mage, 1 warlock, and 1 Palladin while in Horde there is no streamers playing warrior. The Horde's streamers are 1 Shaman, 1 Rogue, 1 Druid and 2 Mages.

The popularity of streamers such as Asmongold that dominated the Alliance faction is actually does play dominant role for the popularity of Faerlina US among the Twitch followers but among Youtube subscribers the Horde is more popular in Faerlina US. 


\section{TWITCH STREAMERS FOLLOWERS}

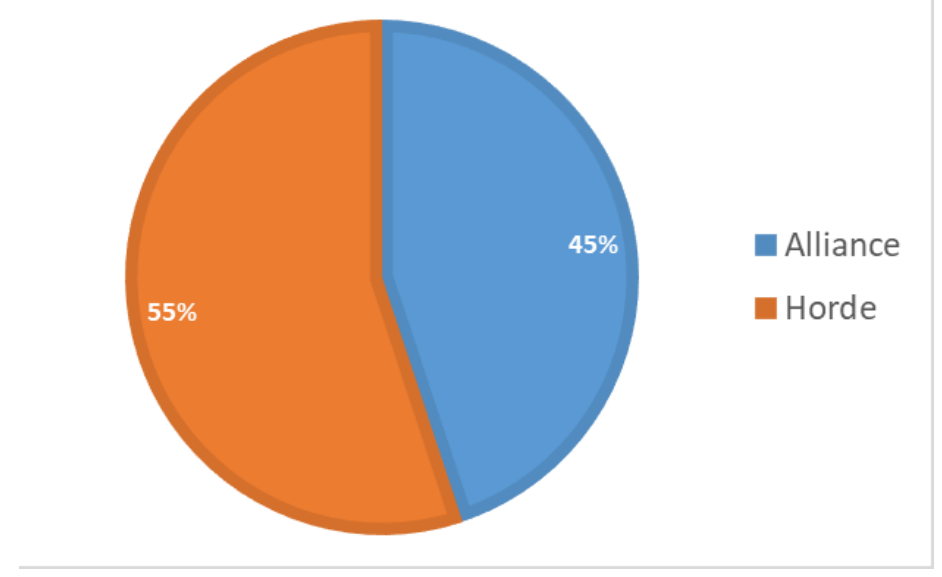

Figure 2. Twitch Streamers followers

The pie show that Alliance is more popular in Faerlina US for the Twitch followers that follow streamers that play in Alliance. While in Horde streamers popularity is stronger based on Youtube subscribers.

\section{YOUTUBERS SUBSCRIBERS}

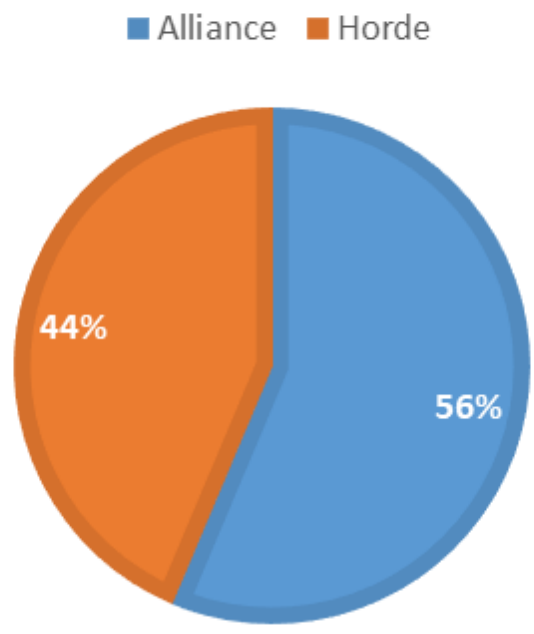

Figure 3. Youtubers subscribers from streamers account

\section{CONCLUSION}

So the popularity of the server Faerlina US is undoubtly not just because of the game itself. Because beside Faerlina US WoW Classic in North America regions offers many servers exactly 26 Player Versus Player Servers - PVP Servers and 9 Normal Servers. It is clearly the 
impact of players that also streamers have shown that many players have affiliate with those Streamers. The channel Twitch and Youtube show a significant role to popularize Faerlina US among the WoW Classic players.

Players that play in Faerlina US beside playing WoW Classic they login their characters because the impact of over population of Faerlina US and its popularity. They become more in-game experience through the presence of the gamer streamers.

\section{REFERENCES}

Hilde G. Corneliussen and Jill Walker Rettberg. (2008). Digital Culture, Play, and Identity, The MIT Press.

Bonnie A Nardi (2010). My Life a night elf priest an Anthropological account of World of Warcraft, University of Michigan Oress.

Arthur Asa Berger (2002). Video Games a popular culture phenomenon, Transaction publishers, P.7

Daniel Muriel and Garry Crawford. (2018)/ Considering the role of video games in contemporary society, Routledge.

John Storey. (2014). $6^{\text {th }}$ Edition, Cultural Theory and Popular Culture An Introduction, Routledge, P.5.

Carvalho, S. and White, H. (1997). Combining the quantitative and qualitative approaches to poverty measurement and analysis: The practice and the potential. World Bank Technical Paper 366. Washington, D.C.: World Bank.

Joël Billieux, Martial Van der Linden,Sophia Achab,Yasser Khazaal,Laura Paraskevopoulos,Daniele Zullino,Gabriel Thorens. (2013). Why do you play World of Warcraft? An in-depth exploration of self-reported motivations to play online and in-game behaviours in the virtual world of Azeroth. Computers in Human Behavior. Elsevier. P. 103-109

Jøn, Allan. (2010). The Development of MMORPG Culture and The Guild. Australian Folklore: A Yearly Journal of Folklore Studies. 25. 97-1

Kawulich, Barbara B. (2005). Participant Observation as a Data Collection Method [81 paragraphs]. Forum Qualitative Sozialforschung / Forum: Qualitative Social Research, 6(2), Art. 43.

Olsen, Wendy. (2004). Triangulation in Social Research: Qualitative and Quantitative Methods can really be mixed, Developments in Sociology, ed. M. Holborn, Ormskirk: Causeway Press.

Williams, D., Ducheneaut, N., Xiong, L., Zhang, Y., Yee, N., \& Nickell, E. (2006). From Tree House to Barracks: The Social Life of Guilds in World of Warcraft. Games and Culture, 1(4), 338-361. https://doi.org/10.1177/1555412006292616

Blizzard Entertainment. (2019). World of Warcraft Classic. 